\title{
Privatization of public assets in developing
} countries

\author{
by Dr K V S K Nathan
}

The author deals with some core understandings and misunderstandings and a few myths in regard to this very popular current tool of economic policies in both developing and developed countries.

I worked for many years as a regular staff member of the World Bank in Washington and most recently as a consultant. I discovered very early in the seventies, even before the Bank itself, the link between law and justice and economic development and how crucial it is for peace and economic growth in developing countries to adhere strictly and passionately to a society ruled by law and not by the arbitrary exercise of personal and political power. In 1803, the great Chief Justice of the US Supreme Court, John Marshall, said it best, albeit in a different context, in the landmark constitutional law case Marbury v Madison (1 Cranch 137 (1803)) when he declared that "The Government of the United States has been emphatically termed a government of laws and not of men." The United States is the richest and most powerful country in the world today.

Privatization is the process of transferring activities carried out by the state and state agencies and other state owned enterprises to be performed by private undertakings (natural and juristic) - privately owned companies, partnerships and associations and individuals. There are numerous publications that cover the technical aspects of privatization. The publications of the World Bank are particularly useful in the analyses of experiences in the developing countries, the methods employed to divest state assets and the obstacles and pitfalls in the privatization of public enterprises. This paper deals with some core understandings and misunderstandings and a few myths in regard to this very popular current tool of economic policies in both developing and developed countries. As Paul Harvey of National Public Radio in the United States would say "You have just heard the news. Here now is the rest of the story".

Privatization in simple practical terms means that some responsibilities to others in the private sector. They may even be encouraged or tempted to join their friends and counterparts in the private sector and that can be a very good thing. More importantly, privatization invariably involves the sale or lease or other disposition of public or state owned assets including land to the private sector. Unfortunately, in the developing countries, it is more likely that the government will be passing on some of its work and responsibilities and divesting state owned assets not to the local private sector but to some foreign business undertaking in a developed country. Those undertakings will be for the most part operating in their own enclave economies within the developing countries under special foreign investment protection laws and bi-lateral investment treaties.

Ironically, too, in many cases of privatization, the government may actually be passing on its work and divesting public assets to a public sector company or state authority in a foreign state such as China, Singapore, France and Italy. It can all be very confusing!. There are real risks in divesting a state enterprise engaged in strategic sectors such as transport, energy, communications and health to a public sector company of another state which can conceivably use it as a weapon, intelligence apparatus or diplomatic arm.

State assets are vast and, if properly managed, their value to the people in terms of social and economic benefits can be great. States, developed and developing alike, own land, ports, air ports, railways, electric power plants and distribution systems, bus companies and gas stations, oil wells and refineries, mines, banks and insurance companies. States hold stock in public and private companies and are engaged in research and development. Some states are involved directly or indirectly in food processing, manufacturing of industrial and consumer 
products, pharmaceuticals and a variety of other businesses and other states are engaged even in the export and import of a variety of commodities. In principle, however, the scope of the public sector covers areas of essential public services and national defense and activities that concern public interests or have natural monopoly or nearmonopoly characteristics. At least, that is the argument governments are prone to advance to maintain ownership and control of the market.

The value of state assets in monetary terms is enormous and the point to remember is that state assets and earnings belong to the people and not to the government du jour and its political supporters. The State in international law can be said to be synonymous with a stable population which it represents through the instrument of Government which consists of, besides the Executive, the Legislative and Judicial branches. No People, no State and no Government. Therefore, in the disposition and disposal of state assets to the private sector there is a duty on the part of the government to ensure that (i) it has the authority to do so under the constitution and the law and (ii) the benefits of such actions accrue to the people generally and not to a privileged few within government and without.

\section{LAW AND PRIVATIZATION}

Although privatization of state assets is primarily a political matter, in many developing countries, it has legal and constitutional implications that are either not understood clearly or are simply ignored by well meaning politicians. They are pressured and often seduced by foreign economic and commercial interests some of them equally well meaning with promises of enriching their economies rapidly in exchange for various concessions to exploit mineral and other key economic resources. They are persuaded by bi-lateral aid agencies and the development banks and the IMF to let the private sector take over state owned enterprises and some of the public services to improve economic performance even if it meant bending the law. East Timor is a recent example that might bring tears to any one sensitive to the plight of unsophisticated developing countries lacking technology and finance but rich in natural resources.

East Timor became independent on Sunday May 19 but, according to the Herald Tribune of May 17, 2002, already "battle lines have been drawn for the oil riches" off its coast. What I cannot comprehend is how oil and gas concessions were signed by the leadership-elect of that unfortunate country even before it became an independent state, all under the auspices of the United Nations. It is shocking that the key natural resources that belong to the people of one of the poorest and least developed parts of the world could have been so easily disposed of even before a viable independent government was in place, had time to set its own vision and goals, develop the key elements of country economic policy and sector development plans, secure the approval of Parliament and prepare for the negotiation of these critical oil and gas deals. Even President Bush had to go to the Congress for its approval for the leasing of the lands in Northern Alaska for the exploration and drilling for oil.

According to the Herald Tribune report, the East Timor oil and natural gas reserves are estimated to be worth US $\$ 40$ billion over 17 years and the East Timor stands to gain only US $\$ 3.2$ billion, about 8 per cent. Why did the World Bank and IMF with all their expertise keep themselves at arm's distance from the transactions that led to the disposal of East Timor people's control of their country's oil and gas deposits? Did the World Bank scrutinize the accuracy of the exploration and production costs and the equity in the share of the revenues?

Are the oil and gas concessions enforceable in law and under the East Timor constitution and what are the consequences if subsequent governments disagree with the present rulers? Why should the capacity to enter into valid contractual relations in international law be less strict than in domestic or municipal law? Has the stage been set in East Timor for future bloody struggles among political parties and the military over a share of the bounty from the oil and gas as it happened in Angola and Congo over oil and mineral riches and in Sierra Leone over diamonds?

The very government that sent advisers to East Timor to help the provisional leadership and made these "deals" is gearing to battle with the East Timor over its maritime boundary because of the oil and gas fields. Australia has already declared its decision to exclude compulsory resolution of the border dispute by the International Court of Justice. Why? Did the leadership-elect of East Timor take the decisions to enter into those deals independently? Were the oil and gas concessions executed under economic duress or economic black mail? Are they legally enforceable in the absence of statutory backing from East Timor's legislative body?

I have absolutely nothing against Australia or other developed country because ours is a competitive world but I only wish that the developing countries pursued their economic and strategic interests as selfishly and tenaciously as the developed countries and used their own independent judgment in the disposal of their mineral and other key economic resources and in the entry into contractual relations that can impact on the countries for generations to come. Worse still developing countries seem to acquiesce, in foreign investment laws, bilateral investment agreements and grants of long term concessions, to conduct and practices damaging to their long term economic and strategic interests and which conduct and practices become over time rules of international law binding developing countries to ill conceived international trade and economic relations. 
A major outrageous project proposal is in the offing in Nicaragua. At a recent presentation to World Bank staff by a group of promoters, support from the Bank was being canvassed for a dry canal project aimed at providing a rail alternative to the use of the Panama Canal. The Bank lawyers did not attend despite the project's constitutional and legal implications for Nicaragua and their repercussions on the social and political stability of the country. Little attention was paid to the fact that Nicaragua was being asked to (i) yield, in effect, sovereignty to foreign investors over a large swathe of land across the country with the risk of the break up of the country into two political units, (ii) overrun the rights of indigenous peoples' rights as well as others and (iii) ignore the benefits to the Nicaraguan economy of alternative integrated development strategies. The sole guaranteed benefit to Nicaragua is to be a relatively modest annual land rent. I felt that the presence of officials from the US Departments of State and Commerce and Industry at the presentation was ominous. I hope that Nicaragua is not so dumb as to agree to the project in its current form.

\section{THE CASE FOR PRIVATIZATION}

Much has been written and said by academicians and practitioners alike and by private and public organizations including development institutions such as the World Bank and the Asian Development Bank and almost all now agree that privatization is a necessary strategy for the developing countries to adopt to improve economic performance and for many countries it is the only route to take to regain solvency. But there is no doubt that in many countries privatization has not been the success it had been touted to be, the poor have become poorer and been deprived of convenient access to basic housing, health and educational needs and that a privileged minority has grossly benefitted directly from the implementation of government programs to dispose of state owned assets.

Nonetheless, there are severe practicable problems inherent in a government continuing to own and operate commercial enterprises. The pressures are not there for the state enterprise to be a viable commercial entity. Managers are usually political appointees who can become complacent and inefficient in the knowledge that they cannot be forced out. Governments often ignore the bottom line and intervene to further political objectives such as diverting funds to the party in power, buying off trade unions, for example, by preventing lay offs of redundant labor and staff, granting enhanced wage settlements and giving employment to party supporters at election time. Governments are also not averse to controlling prices to contain inflation or maintaining uneconomic services to political constituencies.

Governments are also unvilling to submit state owned enterprises to the rigors of an open competitive market and arrogate to themselves monopoly rights in the sectors in which they are active. In other words, their survival is not dependent upon pleasing the customer and the incentives are insufficient for even public-private joint ventures in such circumstances to improve financial efficiencies. The managers of state owned enterprises and public-private joint ventures expect the government to break their fall when it happens. The upshot is that total or partial state ownership tend to discourage competition in the market and encourage government pursuit of policies to underpin particular interests mainly those that will enable unpopular governments to continue in power.

On the other hand, the benefits to local economies of privatization arise only when private undertakings operate within a legal framework that (i) enables them to enter and exit the market easily in an orderly legally defined manner, (ii) compels them to make public disclosures of key company matters especially in sectors that concern local strategic and vital economic interests and (iii) subjects them to an open competitive market by requiring essentially that they do not engage in conduct and concerted practices that impede or distort competition and that they do not abuse a dominant position in the market.

The theoretical justification of privatization is that the private sector is in a better position than the government to manage tasks of a commercial nature because of the flexible institutional and legal rules that govern private undertakings and that, in an open competitive market, privatization of public enterprises results in industrial efficiency and the most efficient and optimal allocation and use of local human, natural and other economic resources. Privatization also attracts private capital, local and foreign, into sectors traditionally operated by the state such as transport infrastructure, telecommunications, utilities, health and education.

\section{PRIVATIZATION EXPERIENCE}

However, the early efforts in privatization that took place in Latin American countries such as Peru, Venezuela, Mexico and Argentina in the eighties and later in Indonesia were primarily for practical reasons such as for purposes of reducing the public debt and sometimes mistakenly to meet current expenditures. The conservative government in Britain under Mrs Thatcher and the United States were probably driven by economic dogma. Russia seized on this and, with USAID-financed academicians teaming in the halls of the Kremlin, embarked on a wholesale disposal of valuable state assets without adequate preparation. Huge profits were made almost overnight by the privileged purchasers of the state's assets. Those involved ignored law and good practice for the sake of implementing policy. Other countries such as France which began initiating privatization programs under the first Chirac government because it enabled the state to focus on its natural mission and functions, namely, to promote and defend public interests, security, safety and health and education. 
In many developing countries, the large size of the public sector is a threat to economic growth because it usually meant that scarce resources were being used to prop up failing state enterprises. Privatization is commonly perceived as a device for ridding the government and government agencies of excessive staff and labor. The result often was to miss out on the other ingredients such as programs to redeploy the labor force and the enactment of anti-trust legislation and competition rules that are absolutely necessary to make privatization an economic and political success. Moreover, privatization schemes aided by World Bank and other donor and aid agencies can result in the creation of new state agencies to channel funds to the local private sector, to attract foreign investors, to administer the privatization processes and to perform regulatory functions. The expansion of the size of the public sector continues to remain unabated in the developing countries.

Peru and Venezuela and Indonesia are now in turmoil and the World Bank and donor and aid institutions have programs to relieve poverty in these and other countries. Mexico went through a severe economic and banking crisis in the late nineties and was only saved by massive aid from the US and the IMF. Its long term sustainability is still unclear. Argentina, despite all its resources and natural wealth, is the recent victim of its past policies - it had completely privatized its economy at a rapid pace by the mid-nineties. It has accumulated over US $\$ 120$ billion in foreign debt and is practically broke and is struggling to feed its own children. Brazil is beginning to show symptoms of another catastrophe.

In Russia, the Yeltsin government was on a privatization spree of unprecedented proportion. The vast capital flight that followed was inevitable and millions across the country are barely surviving because of the absence of both public and private investment. The funds generated by Russia's privatization measures and, for that matter, Argentina's, are largely invested abroad. These and many other developing countries now rely on huge amounts of funding from the World Bank and IMF whose funds have been consistently used as a vehicle to move capital abroad.

Many developing countries have embarked on ambitious plans to privatize public undertakings, some for very sound economic reasons and some, unfortunately, for dubious purposes. The privatization objective of generating export earnings is questionable if the earnings are not managed and accounted for properly. They are far more likely to be invested or otherwise expended abroad. To get rid of excess staff and labor by passing on the responsibility to a private purchaser of state assets does not still relieve the government of the social and political problem of having to deploy the staff and labor affected elsewhere. In a corrupt public environment, the sale or other disposition of state assets such as awards of concessions and leases can also yield generous fees and commissions for friends and relatives of government leaders and lead to capital flight.

\section{BACK TO THE FUTURE}

One would think that in both developing and developed, the state had always owned many of the undertakings they own now but actually it was not so. Immediately after the second world war, countries in Europe began systematically to nationalize private enterprises operating in key sectors of their economies - steel, coal, oil refineries, ports, energy, railways, civil aviation. Holding companies were created by the state to own stock in other private companies across the board. As recently as 1981, France under Mitterand began an extensive program of nationalization. In countries such as Britain, France and Italy, the state was involved widely in many productive sectors of the economy. The involvement in business enterprises of the Italian state and government and political parties is so pervasive that every one in Italy in a significant entrepreneurial activity is touched by the state. The socialist governments during the aftermath of the second world war and even much longer held to a theory that the state must own public services and production and resources of public interest.

We have to note that these same countries, Britain, France and Italy are very prosperous countries today despite the fact that much of their economic growth occurred before their commitment to privatization as a major objective of their economic policies. What it means is that there are other factors such as ill managed government institutions and an unreliable legal order which can retard economic growth in developing countries besides the mere fact of state ownership of economic and commercial enterprises and that it may be short sighted to think that privatization is a kind of panacea for the economic evils persistent in the developing countries. Fortunately, the developed countries during their process of evolution and economic growth were not faced with the external economic and financial and diplomatic pressures that the governments of developing countries face today.

The developing countries when they got their independence evidently copied their colonial masters and with advice from these countries a whole slate of state enterprises was created. In a sense, therefore, the current programs to privatize the very same industries that were in private hands before nationalization are indeed a case of going back in time to the future. That is not to say that privatization is bad economic policy but it does mean that, in any event, privatization or not, strong relatively incorruptible government institutions and efficient and reliable legal, law enforcement and judicial systems are absolutely necessary and, as can be seen from the experience of Peru, Venezuela, Argentina, Brazil, Indonesia and Mexico, more so for the successful implementation of privatization programs. The governments can then focus on their natural mission and purpose, namely, to defend the interests, safety and health and education of their peoples. 
France, for example, was driven to divesting the government from the control of and involvement in hundreds of business enterprises not for reasons of economic efficiency or dogma like Britain and the United States, because the French state enterprises still are some of the best run and efficient undertakings in Europe, but rather by France's concern that governments should not be distracted from their natural mission and purpose. It is conceivable that the generally better health, education and living standards in France are due to the priority given by the government to such concerns - to govern in the public interest rather than to promote privatization for privatization sake.

\section{PRIVATIZATION STRATEGIES}

Privatization, in its purest sense, involves the transfer of the assets and interests of a state entity or state owned undertaking to private ownership with the responsibility for control, management and financing shouldered absolutely by the new private owner who can dispose of the acquired assets and interests in any way the law permits. This strategy would apply especially to disposals of purely commercial enterprises involving manufacturing and sales of goods and services of no public interest. In fact, the private owner may even shut down the activity if the private owner wishes to do so like all failing private undertakings. At the other extreme is the common practice of government departments to give out on contract to private contractors the execution of various tasks or projects e.g. construction of roads and offices, supply of goods and provision of discrete services. There is nothing novel in this as many private companies too out source many of their in-house tasks to sub-contractors. It is generally agreed that the outsourcing of government work by contracting with outside private suppliers of goods and services including civil works contractors is not privatization and is perfectly legal.

There is generally no prohibition against outsourcing by government departments and statutory authorities but under certain circumstances they can be illegal particularly if a statutory function is judicial or quasi judicial. Broadly speaking, in a respected democratic society every duty of a government servant has to be discharged in a fair and just manner and that means in a judicial manner. For example, is a government tender board award of a contract to a private contractor for the construction of a road or port terminal on the recommendation of an outside World Bank-financed consultant a lawful exercise of the tender board's role as the authority to decide on such awards. Indeed, in my World Bank experience, the defense of many government departments when there is controversy over an award is to say that they acted on the advice of a foreign consultant thus acknowledging their unlawful relinquishment of a statutory duty. The extreme case would be where a judge takes a decision on a case before him or her, influenced by the advice of a USAID or
World Bank-financed consultant lawyer engaged in a law and judicial reform project.

In between, there are various privatization strategies depending on the type of assets - utilities, mining, transport, hospitals, schools, oil, research, banking and insurance - the competitiveness of the industry or sector, the public interest at stake and the size of the capital markets at home and abroad. Various techniques are employed but, in general, the governments maintain some sort of link with the private enterprise taking over the state assets either directly by participating in the organization, stock holding and direction of the privatized enterprise or indirectly through regulatory mechanisms. These links between the government and the privatized enterprise are particularly strong in the developed countries which provide in their privatization schemes for measures against any attempt by a foreign investor to take control of the privatized industry, sector or enterprise and measures against predatory trade, business and company practices.

\section{KEY TO SUCCESSFUL PRIVATIZATION}

In any event, the privatized state enterprises in the developed countries such as Britain, France and Italy operate within the local legal, economic, monetary and banking and tax systems and are thus fully integrated into the local economies. There are no bilateral agreements with the countries of origin of the foreign investors other than for free trade, no sovereign guarantees, no freezing of the law governing the transactions, no assurances of compensation for damages caused by Acts of God and foreign events except in the public interest under the general law, no authorizations of payments and receipts other than through the local banking system and the central banks, no privileged position in the market, no obligations to stabilize local taxes and no exemption from current local taxes and duties other than incentives provided under the law generally to special sectors and industries.

In other words, for privatization to achieve the widely accepted economic development objectives, namely, accrual of the benefits to the whole economy, securing the best price for the sale or other disposition of the state enterprise, assuring enterprise efficiency and performance, accessing capital and know-how, and expanding local capital markets, (i) a strong anti-trust and competition law to govern the market and associated institutions should be in place and (ii) all transactions should be made within the local legal, economic, monetary and banking and tax systems.

Before proceeding with the privatization exercise it would be necessary to prepare the state enterprise for the proposed mode of divestment to the private sector. This would necessarily involve (i) the determination of the constitutionality of privatization in any particular case, (ii) the construction of a legal framework that provides for the 
validity in law of the various steps to be undertaken, and (iii) the establishment of a regulatory body where appropriate.

The preliminary question always is whether an action to be taken by the government to involve the private sector particularly in the provision of public services and services rendered by statutory authorities such as a Ports Authority is a divestment of state assets falling within the definition of privatization prohibited under the constitution and the governing statute. For example, under authority given in the preamble to the French Constitution of 1946 requiring the state to take over all private undertakings that were connected with the provision of a public service, hundreds of private undertakings were nationalized. The 1958 Constitution provided for the French legislature to pass laws, inter alia, to do the reverse, namely, the divestiture of public property to the private sector. Britain, by contrast, had no constitutional impediments because it has no defined constitution but was nonetheless constrained to privatize state enterprises only under legislation enacted by Parliament as in France. In fact, the introduction of private management by contract of the Royal Dockyards had to be carried out under a special Act of Parliament.

The question that pops up in many developing countries is whether private investment in and management of assets of statutory authorities engaged in providing public services such as ports and airports and toll roads and power plants under so-called BOT (BuildOperate-Transfer) projects are legal without special legislation. Is a concession granted without the approval of parliament to a private undertaking for investment in a port terminal or expressway and its absolute control and operation for periods of thirty years or longer until the investment is recovered an illegal transfer of statutory functions to a private undertaking? What it means is that both the government and the concessionaire have to assure themselves that the transfer of state assets and responsibilities for public services to the private sector is valid under the constitution and the law of the country concerned.

One way to avoid controversy over the legality of privatization of any particular state enterprise in any particular manner is to enact a general law to authorize the divestiture of state assets setting out the definition and scope of privatization and the procedures to be adopted to privatize state enterprises. For example, the Turkish Law on Privatization permitted the government not only to decide which state enterprises to privatize but also to decide on the percentage of assets and equity to be sold, leased or granted operating rights. Distinctions are made between state enterprises engaged in manufacturing, trade and commerce in goods and services of no special character and those enterprises that deal in goods and services that are perceived as basic to the needs of the people or have strategic value or have characteristics of a natural monopoly - energy, water, transport, aviation, ports. In France, a single piece of legislation in 1986 empowered the government to privatize state enterprises while in Britain a specific piece of legislation was introduced for sale or other disposition of each state enterprise.

\section{PRIVATIZATION TECHNIQUES}

The techniques that are commonly employed in the privatization of state assets include the public offer of shares in a joint stock company, private sale of shares or sale of an entire state enterprise, management and employee buyouts, grant of concessions, public-private joint ventures or a combination of these. Losing undertakings could just be folded up and their assets sold to the highest bidder. The government could simply sell the undertaking to the highest bidder as is or after some revamping, restructuring or subdivision, form a joint stock company and sell the shares to the public and core investors under different formulae or sell stocks and shares held by state holding companies in the stock market. Debt could be swopped for equity. Each sector and state enterprise has to be examined for its particular characteristics to be able to implement a privatization scheme with wide public support. In Britain, government housing units were sold to their occupants with minimum formalities.

Public utilities belong to a group of economic and commercial activities that are of public and strategic interests besides possessing elements of a natural monopoly to varying degrees depending on the type of utility - water, gas, electric power, telecommunications. Because of the lack or absence of competition in the market in the goods and services those utilities sell, they are not subject to the disciplines that lead to industrial efficiency. The consequences to the consumer in regard to availability, price and quality of goods and services can be negative unless there is intervention by the government. In some strategic and defense areas such as transport, energy, water, the powers of the government to intervene can be critical.

Government intervention can either be through powers exercised by various government departments as in France or through regulatory agencies specially established by statute for each industry or sector as in Britain and the United States. The drawback in the British and US practices is that new agencies are created thus defeating one privatization objective, namely, the reduction in the size of government and, in Britain, regulatory agencies tend to cosy up to the principal players in the privatized sector or industry - old school tie, royal honors and so on. The civil law systems such as in France and Italy can be relied upon more to place public interest over everything else with the result that there is much more sensitivity to worker rights, the gaps between the rich and the poor are far more contained and society has a less divisive character. Of course, this can change. 
The Regulator is a unique institution in that it performs a variety of conflicting tasks that would be regarded as repugnant by a purist believer in democratic rights and freedoms. The overall role of the Regulator is to monitor, direct and control or govern the conduct of companies and other undertakings engaged in the market in a particular industry or sector in accordance with a privatization statute or law or rule in the context of the fundamental values of a whole legal and economic and social system. The Regulator is an executive first and foremost in its capacity of issuing licenses and permits and supervising the functioning of the market but usually has powers to enact rules and regulations for the detailed operation of the industry or sector concerned, interpret the law and adjudicate disputes between companies and other undertakings and their customers. He can successively be an executive, legislator and judge. In a sense, therefore, there is a rationale and indeed legitimacy in subjecting the privatized industry or sector to the supervision of all the departments of government but in certain sectors the sharing of regulatory functions among several government departments can be unwieldy and cumbersome.

\section{CONCLUSION}

Since a government consists of three branches, namely, executive, legislative and judiciary, any privatization scheme that is adopted by the executive on behalf of the government involving the disposal or disposition of land, natural and other key economic resources should have the approval of the legislative body and be sustainable in the local courts of law.

Because of severe distortions in the local markets due to the absence of a competitive law framework and irregularities in the divestment procedures and because of continued invasive links between the private sector and the governments, privatization in developing countries has resulted in increased prices, increased levels of unemployment and neglect of services particularly to politically weak and vulnerable segments of the population. Nonetheless, it is safe to say that purely commercial enterprises should be left to the private sector to own, control and manage.

However, in regard to strategic areas such as defense, home security, energy, water supplies, transport infrastructure, ports and airports, communications and sectors such as education and health and social services, it would be risky, if not dangerous, to leave ownership and control in the hands of the private sector especially foreign based private enterprises and foreign state agencies. In those areas, it would be prudent to involve the private sector only under contractual arrangements under conditions that do not transfer absolute control to the private enterprises.

Countries such as France and Italy have shown that states can manage enterprises even of a commercial nature as well as the private sector and some major companies in the private sector have demonstrated how corruptible they can be. Economic dogma aside, the powerful rationale for privatization is the view, which I believe is shared by France, that the government should privatize public assets to enable it to focus on its natural purpose and mission, namely, to protect and defend the vital interests, security, safety, health and education of its people.

The proof of a successful privatization exercise is not so much the improvement in performance per se (increased output and sales and lower labour and other costs and higher profits) of the privatized activity as the direct and indirect long term benefits to the local economy. It is conceivable that the current spate of disposal of natural and other key economic resources of developing countries to foreign companies sets the stage for (i) civil strife as different segments of the society vie for a share in the profits of the sale and use of the public assets and (ii) ultimate intervention by the developed countries to protect their people and their proprietary and trading interests and their benefactors in government. The ghosts of the East India Company seem to be everywhere. I am afraid that the World Bank and the IMF are unwitting partners in this development.

\section{Dr K V S K Nathan}

Barrister/Arbitrator, Mestrino (PD), Italy

This article is based on a talk on privatizing public assets delivered to the Sri Lanka Institute of Project Managers at its Annual General Meeting and Dinner on March 31, 2002. Dr Nathan is the author of the book "The ICSID Convention The Law of the International Centre for Settlement of Investment Disputes" published by Juris Publishing, New York (2000). 